\title{
Avaliação de parâmetros biométricos de cascos de equinos atendidos no Hospital Escola de Medicina Veterinária do Centro Universitário de Itajubá
}

Natália Gonçalves Santana Procópio", Luan Gavião Prado, Lucas de Moura Sampaio, Larissa Cerqueira Barboza, Inaia Roberta Silva

Centro Universitário de Itajubá (FEPI), Itajubá, MG, Brasil

*Autor correspondente

e-mail: nataliasantana20@live.com

\section{Resumo}

Durante sua evolução, os equinos sofreram adaptações para locomoção em altas velocidades, incluindo a simplificação da região distal a um único dígito. 0 casco encontra-se na parte distal dos membros, que por sua vez compreende: duas fileiras de osso do carpo, um único osso metacarpal formado para dedo e três falanges dentro de cada dedo. As falanges média e distal articulam-se na articulação do casco. 0 casco é uma modificação cornificada da epiderme onde se localiza uma camada vascular. A coroa é a região responsável pela produção da queratina do casco. Quando em estação, a porção do casco visível é a parede, dividida em pinça na vista frontal, em quartos medial e lateral, e em talões medial e lateral na vista traseira, que giram agudamente em direção aos ângulos para serem continuados pelas barras na parte mais baixa do casco. Entre as anormalidades de equilíbrio podal, destacam-se o desnivelamento dorso-palmar e médio-lateral, contração dos talões e ranilha, diferença entre o ângulo da pinça dos cascos contralaterais e tamanho do casco em relação ao peso do animal. Por fazer parte da sustentação e concussão, é importante realizar a biometria para saber a proporção correta e para descobrir as causas de claudicação e desequilíbrio existentes em diferentes raças. 0 método de avaliação biométrica dos cascos constitui em um processo de diagnóstico eficiente. Realizou-se a mensuração das seguintes estruturas anatômicas: ângulo e comprimento da pinça, comprimento e largura da sola, comprimento e largura da ranilha, distância do ápice da ranilha à parede medial/lateral do casco na superfície solear, altura da muralha medial/lateral, circunferência da superfície de contato do casco (equivalente à circunferência aspecto palmar do casco). Todas as mensurações foram expressas em centímetros e o ângulo da pinça em graus. Foram encontrados valores médios de 18,75으 para angulação de pinça, $32,6 \mathrm{~cm}$ para diâmetro de coroa, 7,73 cm para comprimento de ranilha, 3,7 cm para largura de ranilha, 11,96 cm para comprimento de sola, 10,2 cm para largura de sola, 3,36 cm para altura de talão, 6,6 cm para os quartos medial e lateral da muralha do casco e 8,8 cm para comprimento de pinça. 
Os dados observados mostram que a biometria realizada com os animais atendidos no Hospital Escola de Medicina Veterinária - FEPI foram inferiores quando comparados com alguns trabalhos: diâmetro de casco $(<0,4)$, comprimento de ranilha $(0,7)$, largura da ranilha e largura de sola $(<1,0)$, comprimento de sola $(<$ $0,7)$, altura de talão $(<0,5)$, comprimento de quartela $(<0,3)$, porém os valores de comprimento de pinça foram iguais. Já em comparação a outro trabalho, as mensurações apresentaram-se inferiores nas avaliações de comprimento de pinça $(<0,5)$, comprimento de sola $(0,9)$ e largura de sola $(<1,3)$, entretanto o valor se manteve igual em comprimento de ranilha; já os valores de diâmetro de coroa, altura de talão, comprimento de quarto não foram encontrados. No presente trabalho foram avaliados animais provenientes de diferentes áreas da região, os quais não recebem o mesmo tipo de alimento, nem volumoso nem concentrado. Além disso, os pacientes atendidos apresentavam diferentes patologias de base que podem influenciar no crescimento e na biometria dos cascos; tais diferenças podem influenciar nas medidas realizadas. Os resultados encontrados não diferem drasticamente com a literatura nacional disponível. Os dados gerados a partir desta pesquisa podem ajudar médicos veterinários a realizarem casqueamentos e ferrageamentos de forma correta a fim de evitar futuros danos ao aparelho locomotor dos equídeos.

Palavras-chave: Biometria. Casco. Desequilíbrio.

Agradecimentos: ao Centro Universitário de Itajubá - FEPI pela bolsa concedida e à Fundação de Amparo à Pesquisa de Minas Gerais - FAPEMIG. 